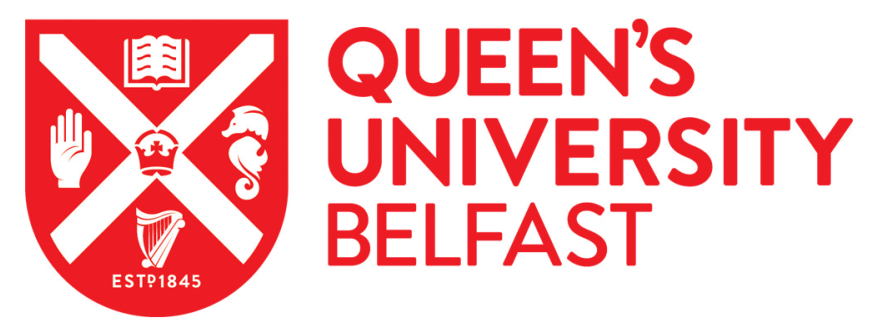

\title{
Contribution of arbuscular mycorrhizal fungi to utilization of organic sources of phosphorus by red clover in a calcareous soil
}

Feng, G., Song, Y. C., Li, X. L., \& Christie, P. (2003). Contribution of arbuscular mycorrhizal fungi to utilization of organic sources of phosphorus by red clover in a calcareous soil. Applied Soil Ecology, 22(2), $139-148$.

Published in:

Applied Soil Ecology

Queen's University Belfast - Research Portal:

Link to publication record in Queen's University Belfast Research Portal

\section{General rights}

Copyright for the publications made accessible via the Queen's University Belfast Research Portal is retained by the author(s) and / or other copyright owners and it is a condition of accessing these publications that users recognise and abide by the legal requirements associated with these rights.

Take down policy

The Research Portal is Queen's institutional repository that provides access to Queen's research output. Every effort has been made to ensure that content in the Research Portal does not infringe any person's rights, or applicable UK laws. If you discover content in the Research Portal that you believe breaches copyright or violates any law, please contact openaccess@qub.ac.uk. 


\title{
Applied Soil Ecology
}

\section{Contribution of arbuscular mycorrhizal fungi to utilization of organic sources of phosphorus by red clover in a calcareous soil}

\author{
G. Feng ${ }^{\text {a }}$, Y.C. Song ${ }^{\text {a }}$, X.L. Li ${ }^{\text {a }}$, P. Christie ${ }^{\mathrm{a}, \mathrm{b}, *}$ \\ a Department of Plant Nutrition, College of Agricultural Resources and Environmental Sciences, \\ China Agricultural University, Beijing 100094, PR China \\ b Agricultural and Environmental Science Department, Queen's University Belfast, Newforge Lane, Belfast BT9 5PX, UK
}

Received 21 May 2002; received in revised form 5 September 2002; accepted 9 September 2002

\begin{abstract}
A glasshouse pot experiment investigated the uptake by arbuscular mycorrhizal (AM) fungi associated with red clover of three organic sources of $\mathrm{P}$ added to a sterilized calcareous soil of low $\mathrm{P}$ availability. Each pot was separated into a central compartment for plant growth and two outer compartments for external mycelium using 30- $\mu$ m nylon mesh to restrict the roots but allow hyphal penetration. Plants in the central compartments were inoculated with the AM fungus Glomus versiforme and uninoculated controls were included. Plants were harvested on three occasions: 5, 7 and 10 weeks after sowing. Application of each of the three organic $\mathrm{P}$ sources (lecithin, RNA and sodium phytate) or inorganic $\mathrm{P}\left(\mathrm{KH}_{2} \mathrm{PO}_{4}\right)$ at $50 \mathrm{mg} \mathrm{P} \mathrm{kg}^{-1}$ to the outer compartments of mycorrhizal and uninoculated pots increased the yield, $\mathrm{P}$ concentration and total $\mathrm{P}$ uptake of red clover compared with pots to which no $\mathrm{P}$ was applied, with no differences among P sources in non-mycorrhizal plants but differences observed in mycorrhizal plants both 7 and 10 weeks after sowing suggesting differences in availability of the four P sources to AM mycelium. The contribution of external mycelium to plant uptake of applied $\mathrm{P}$ increased with time. The three organic $\mathrm{P}$ sources made smaller contributions to plant $\mathrm{P}$ nutrition than $\mathrm{KH}_{2} \mathrm{PO}_{4}$ at the first and second harvests. At the third harvest, the contribution from $\mathrm{KH}_{2} \mathrm{PO}_{4}$ was $23 \%$, while those from lecithin, RNA and sodium phytate were 23,17 and $31 \%$, respectively. This suggests that with the mediation of AM fungi, soil organic $\mathrm{P}$ sources can make a contribution to host plant $\mathrm{P}$ nutrition comparable to that of soluble orthophosphate.
\end{abstract}

(C) 2002 Elsevier Science B.V. All rights reserved.

Keywords: Trifolium pratense; Glomus versiforme; Lecithin; RNA; Sodium phytate; P uptake

\section{Introduction}

Organic P comprises $30-80 \%$ of total soil P (Dalal, 1977) and is an important potential source of $P$ for plants in most agricultural soils. The three principal groups of organic $\mathrm{P}$ compounds are the inositol phosphates (e.g. phytate), phospholipids (e.g. lecithin),

\footnotetext{
* Corresponding author. Tel.: +44-28-9025-5335; fax: +44-28-9025-5005.

E-mail address: p.christie@qub.ac.uk (P. Christie).
}

and nucleic acids (e.g. RNA) and their degradation products or derivatives (Stevenson and Cole, 1999). Some attention has been paid to the bioavailability and contribution of soil organic $\mathrm{P}$ sources to plant $\mathrm{P}$ nutrition in recent years (Li et al., 1997a,b; Hayes et al., 2000a,b). The various forms of organic P differ in their lability to phosphatase enzymes released by plant roots or microorganisms in soil, and this results in differences in their availability to plants with the declining order of: lecithin $>$ RNA $>$ phytate (Bowman and Cole, 1978; Stevenson and Cole, 1999). 
Several studies have shown increased plant $\mathrm{P}$ uptake from inositol hexaphosphate following inoculation of growth substrates with bacteria, soil fungi and mixed populations of soil microorganisms (Richardson et al., 2000; Tarafdar and Marschner, 1994, 1995).

To become available for plants, organic P compounds must be hydrolyzed by a group of enzymes called phosphatases or phytases which may be of plant or microbial origin (Theodorou, 1971; Tarafdar and Claassen, 1988; Tarafdar and Marschner, 1994; Hayes et al., 1999; Li et al., 1997a,b; Richardson and Hadobas, 1997). Some investigations have confirmed that utilization of organic $\mathrm{P}$ is enhanced by arbuscular mycorrhiza. This enhancement effect could be due to both an increase in surface area and phosphatase activity of the extraradical hyphae (Li et al., 1997a; Tarafdar and Marschner, 1994). It is well established that arbuscular mycorrhiza can increase the $\mathrm{P}$ uptake of plants through the extraradical hyphae under certain conditions, but most research has dealt with inorganic $\mathrm{P}$ and few investigations have considered the utilization of organic $\mathrm{P}$ compounds by AM plants (Jayachandran et al., 1992; Joner and Jakobsen, 1994; Cade-Menun and Berch, 1997).

The relative contribution of soil organic $\mathrm{P}$ sources to plant $\mathrm{P}$ nutrition is therefore poorly understood. The role of AM fungi in the mineralization of organic $\mathrm{P}$ in soil and the contribution of $\mathrm{P}$ directly absorbed by AM fungal mycelium from soil organic $\mathrm{P}$ sources to plant $\mathrm{P}$ nutrition are thus unclear (Joner et al., 2000). The aims of this study were to identify the influence of AM fungi on the availability of three organic $\mathrm{P}$ sources to plants, follow changes in the hydrolysis of the organic $\mathrm{P}$ compounds in soil as affected by phosphatases released by AM fungi during plant growth, and estimate the contribution of $\mathrm{P}$ absorbed by AM external mycelium to plant total $\mathrm{P}$ uptake.

\section{Materials and methods}

Plants were grown in acrylic (Plexiglas ${ }^{\mathrm{TM}}$ ) pots separated into three compartments by $30-\mu \mathrm{m}$ nylon mesh to allow the spatial separation of soil zones for root and mycorrhizal hyphal growth. The central compartment was used for root growth and the two outer compartments for growth of arbuscular mycorrhizal hyphae (Li et al., 1991). The calcareous loamy soil was collected from field plots receiving $270 \mathrm{~kg}$ fertilizer $\mathrm{N} \mathrm{ha}^{-1}$ year $^{-1}$ at Changping Long-Term Fertilizer Station of China Agricultural University in Beijing. The soil had $1.24 \%$ organic C, $2.6 \mathrm{mg} \mathrm{kg}^{-1}$ Olsen-P, $87.2 \mathrm{mg} \mathrm{kg}^{-1} \mathrm{NaOH}$-extractable $\mathrm{N}, 100 \mathrm{mg} \mathrm{kg}^{-1}$ ammonium acetate-exchangeable $\mathrm{K}$, and a $\mathrm{pH}$ value (in $\left.\mathrm{CaCl}_{2}\right)$ of 7.5. The soil was air dried, sieved $(<2 \mathrm{~mm})$, and steam-sterilized. The central compartment of each pot contained $100 \mathrm{~g}$ and each outer compartment contained $360 \mathrm{~g}$ of air-dried sterilized soil.

Glomus versiforme (Karsten) Berch was propagated on maize roots and inoculum consisted of spores, mycelium, fine root segments and soil. The fungus was kindly donated by Professor Honggang Wang, Institute of Soils and Fertilizers, Chinese Academy of Agricultural Sciences, 30 Baishiqiao Road, Haidian District, Beijing 210008, PR China. The fungus has not been lodged in an international culture collection but can be obtained directly from Professor Wang. Fifteen grams of inoculum were placed in the central root compartment of the mycorrhizal pots and $15 \mathrm{~g}$ of sterilized inoculum were added to the non-mycorrhizal pots. Ten milliliters of washings of the inoculum filtered to remove arbuscular mycorrhizal propagules were added to the central compartment of the non-mycorrhizal treatments to minimize differences in the rhizosphere microbial communities of mycorrhizal and non-mycorrhizal plants.

The experiment had five main treatments: $50 \mathrm{mg}$ $\mathrm{P} \mathrm{kg}^{-1}$ soil applied as $\mathrm{KH}_{2} \mathrm{PO}_{4}$ (analytical grade, Beijing Chemical Co.), RNA (Beijing Chemical Reagents Co.), lecithin (Shanghai Organic Chemical Co.) or sodium phytate (phytic acid (inositol hexaphosphoric acid) sodium salt from corn, cat. no. P-8810, Sigma), and unfertilized controls. Within each main treatment, there were two sub-treatments: inoculation with $G$. versiforme and non-mycorrhizal. In addition, one extra type of mycorrhizal control ('AM control') was included in which the central compartment was separated from the two outer compartments by $0.45-\mu \mathrm{m}$ nylon mesh through which neither fungal hyphae nor roots could pass but which allowed solute diffusion to occur. There were four replicates of each treatment, giving 132 pots in total arranged fully randomly in the greenhouse and with the position of each pot re-randomized every week.

All pots received mineral nutrients which were added uniformly to each compartment at rates of 
$200 \mathrm{mg} \mathrm{N}$ (as $\mathrm{NH}_{4} \mathrm{NO}_{3}$ ), $150 \mathrm{mg} \mathrm{K}$ (as $\mathrm{K}_{2} \mathrm{SO}_{4}$ ), $50 \mathrm{mg} \mathrm{Mg}$ (as $\mathrm{MgSO}_{4}$ ), $5 \mathrm{mg} \mathrm{Zn} \mathrm{(as} \mathrm{ZnSO}_{4}$ ), $2 \mathrm{mg} \mathrm{Cu}$ (as $\mathrm{CuSO}_{4}$ ) and $10 \mathrm{mgCa}\left(\right.$ as $\left.\mathrm{CaSO}_{4}\right) \mathrm{kg}^{-1}$ soil. The pots receiving the different $\mathrm{P}$ sources had $\mathrm{P}$ applied to the two outer compartments at the rate of $50 \mathrm{mg} \mathrm{P} \mathrm{kg}^{-1}$.

Red clover (Trifolium pratense L.) was used as the host plant. Seeds were surface-sterilized in $10 \%$ (v/v) hydrogen peroxide for $10 \mathrm{~min}$ and rinsed at least five times in deionized water. Fifty seeds were sown in each pot and thinned to 20 after emergence. The seedlings grew in a glasshouse at a temperature range of $20-25^{\circ} \mathrm{C}$ and with a photoperiod of $15 \mathrm{~h}$.

The experiment was harvested three times: 35,49 and 70 days after sowing. On each occasion 44 pots representing four randomly selected replicates of each treatment were carefully opened and the compartments were separated. The roots were removed from the central compartment and washed with running tap water. A sub-sample of soil was collected for determination of phosphatase activity. Shoots and roots were washed with deionized water. Roots were cut into $1-\mathrm{cm}$ segments and thoroughly mixed. A sub-sample of $0.5 \mathrm{~g}$ was cleared with $10 \%(\mathrm{w} / \mathrm{v}) \mathrm{KOH}$ at $90^{\circ} \mathrm{C}$ for $2 \mathrm{~h}$ and stained with Trypan blue. Mycorrhizal colonization was assessed by the grid-line intersect method as described by Giovannetti and Mosse (1980). The shoots and the remainder of the roots were oven dried at $70^{\circ} \mathrm{C}$ and the dry weights were recorded. The samples were ground and dry-ashed in a muffle furnace at $300^{\circ} \mathrm{C}$ for $3 \mathrm{~h}$ and at $550^{\circ} \mathrm{C}$ for $5 \mathrm{~h}$. The ash was dissolved using $2 \%$ (v/v) nitric acid. Phosphorus was determined by the molybdovanadophosphate method (Kitson and Mellon, 1944).

From the total $\mathrm{P}$ uptake of the plants, we calculated the amount of $\mathrm{P}$ derived from $\mathrm{P}$ applied to the hyphal compartments by subtracting the $\mathrm{P}$ uptake of unfertilized controls from that of treatments to which $\mathrm{P}$ was applied as follows:

AM hyphal contribution to plant $P$ uptake

$$
=1-\frac{\text { total } \mathrm{P} \text { uptake by non-AM plants } \times 100}{\text { total } \mathrm{P} \text { uptake by AM plants }}
$$

In addition, the $\mathrm{P}$ absorbed by external mycelium from the $\mathrm{P}$ applied to the hyphal compartments was calculated by subtracting the amount of $\mathrm{P}$ derived from added sources by non-mycorrhizal plants from that derived by mycorrhizal plants. The proportion of total $\mathrm{P}$ uptake taken up by the mycelium was then calculated as a percentage to compare the contribution of $\mathrm{AM}$ mycelium to the total plant uptake of $\mathrm{P}$ from the various sources of applied $\mathrm{P}$ as follows:

$$
\begin{aligned}
& \text { AM hyphal contribution to plant uptake of applied } \mathrm{P} \\
& =\frac{\mathrm{P} \text { uptake by AM mycelium }}{\text { total } \mathrm{P} \text { uptake }}
\end{aligned}
$$

The contribution of native soil $\mathrm{P}$ to plant $\mathrm{P}$ nutrition was calculated and the contribution of $\mathrm{P}$ uptake by hyphae from the soil was calculated by subtracting the total $\mathrm{P}$ uptake of non-mycorrhizal plants from the total P uptake of mycorrhizal plants as reported previously by Tarafdar and Marschner (1995):

AM hyphal contribution to uptake of soil native $P$

$$
=100-\frac{\mathrm{P} \text { uptake by AM mycelium }}{\text { total } \mathrm{P} \text { uptake }}
$$

Data were subjected to analysis of variance using the GENSTAT 5 statistical package (GENSTAT Committee, 1994) in a factorial design of five applied $\mathrm{P}$ sources (including no-P control) $\times$ two mycorrhizal colonization treatments + one 'AM control' (mycorrhizal, as described above) $\times$ three harvest dates $\times$ four replicates. A separate set of 44 pots representing four replicates of each treatment was randomly selected for each harvest and destructively harvested to recover shoots and roots. Thus, the data for the three harvests were obtained from different replicates and are statistically independent. Data presented are the means of four replicates with standard deviations. Estimates of $\mathrm{P}$ derived from applied and native soil $\mathrm{P}$ and from uptake by external mycelium were calculated from mean values because the experimental design was fully randomized and not include randomized blocks. These estimates could not therefore be calculated separately for individual replicates and were not amenable to statistical analysis.

\section{Results}

\subsection{Mycorrhizal colonization}

Root growth was dense in the central compartments and the roots were in close contact with the nylon net 
Table 1

Mycorrhizal colonization (\% of root length colonized) at different growth stages of red clover roots inoculated with Glomus versiforme and supplied with inorganic P or organic P sources. Values are means $(n=4) \pm$ one standard deviation (S.D.)

\begin{tabular}{llll}
\hline Applied P source & \multicolumn{2}{l}{ Days after sowing } \\
\cline { 2 - 4 } & 35 days & 49 days & 70 days \\
\hline Control (no applied P) & $46.7 \pm 3.3$ & $59.3 \pm 13.1$ & $58.5 \pm 7.9$ \\
$\mathrm{KH}_{2} \mathrm{PO}_{4}$ & $49.2 \pm 2.8$ & $55.6 \pm 2.5$ & $50.0 \pm 2.0$ \\
Lecithin & $50.1 \pm 5.4$ & $67.3 \pm 3.6$ & $60.3 \pm 5.5$ \\
$\mathrm{RNA}$ & $50.5 \pm 2.4$ & $68.0 \pm 8.3$ & $62.1 \pm 6.6$ \\
$\mathrm{Na}$ phytate & $47.8 \pm 5.0$ & $71.7 \pm 6.7$ & $65.7 \pm 10.4$ \\
'AM control' & $46.2 \pm 4.0$ & $62.1 \pm 2.4$ & $57.6 \pm 1.8$ \\
Significance & & & $\mathrm{NS}$ \\
$\quad \mathrm{P}$ source & & $* * *$ & \\
Harvest time & & $\mathrm{NS}$ & \\
$\mathrm{P}$ source $\times$ harvest time & & & \\
\hline
\end{tabular}

NS, not significant.

${ }^{\mathrm{a}}$ By analysis of variance.

*** $P<0.001$.

separating the root and hyphal compartments. Mycorrhizal colonization rates determined 35,49 and 70 days after sowing of red clover in inoculated pots are shown in Table 1. No mycorrhizal colonization of uninoculated plant roots was observed under the microscope. The plants inoculated with $G$. versiforme had mean colonization rates ranging from 46.2 to $50.5 \%, 55.6$ to $71.7 \%$ and 50.0 to $65.7 \% 5,7$ and 10 weeks after sowing, respectively. There was a general trend of increasing colonization rate at the second harvest with a subsequent slight decrease by the third harvest, but there was considerable variation in the data. There was little difference among $P$ sources in root colonization after 35 days, but at later stages of plant growth, the plants receiving organic $\mathrm{P}$ sources tended to have higher colonization than those receiving inorganic $\mathrm{P}$. The 'AM control' results, in which hyphal growth was restricted to the root compartment, were similar to the conventional controls.

\subsection{Effect of G. versiforme inoculation on growth of clover receiving different $P$ sources}

Mycorrhizal plants had higher dry matter (DM) yields than did non-mycorrhizal plants with all applied $\mathrm{P}$ sources and zero-P controls and at all three harvests (Table 2) and this mycorrhizal effect became more pronounced as plant growth proceeded. All added P sources had similar effects on shoot yield, but root yields were slightly depressed when the added $\mathrm{P}$ source was Na-phytate or RNA. The 'AM control' had shoot and root yields that were intermediate between non-mycorrhizal and mycorrhizal controls. In general, different trends among P sources were mainly due to the fertilizer effect of all $\mathrm{P}$ sources compared with unamended controls rather than differences among added $\mathrm{P}$ sources.

\subsection{Plant $P$ concentrations}

Inoculation with G. versiforme increased shoot and root $\mathrm{P}$ concentrations (Table 3) and this mycorrhizal effect became more pronounced as plant growth proceeded. By the tenth week of growth, mycorrhizal plants with added organic $\mathrm{P}$ sources tended to have higher shoot $\mathrm{P}$ concentrations than those receiving orthophosphate. There was no such effect of $\mathrm{P}$ source on root $\mathrm{P}$ concentration at the final harvest, when mycorrhizal plants receiving RNA had lower root $\mathrm{P}$ concentrations than mycorrhizal plants growing with added inorganic $\mathrm{P}$.

\subsection{Plant P uptake}

Mycorrhizal plants took up more $\mathrm{P}$ than did non-mycorrhizal plants at all three harvests (Table 4) and this mycorrhizal effect became more pronounced as plant growth proceeded. By the third harvest, my- 
Table 2

Shoot, root and total (shoot + root) dry matter yield of mycorrhizal and non-mycorrhizal red clover plants (g per pot) at different stages of plant growth with applied inorganic $\mathrm{P}$ or organic $\mathrm{P}$

\begin{tabular}{|c|c|c|c|c|c|c|c|c|c|c|}
\hline \multirow[t]{2}{*}{ Applied P source } & \multirow[t]{2}{*}{ Mycorrhizal status } & \multicolumn{3}{|l|}{ Shoot } & \multicolumn{3}{|l|}{ Root } & \multicolumn{3}{|l|}{ Total } \\
\hline & & 35 days & 49 days & 70 days & 35 days & 49 days & 70 days & 35 days & 49 days & 70 days \\
\hline Control (no P) & Non-mycorrhizal & $0.35 \pm 0.07$ & $0.68 \pm 0.04$ & $1.06 \pm 0.18$ & $0.09 \pm 0.01$ & $0.25 \pm 0.02$ & $0.26 \pm 0.04$ & $0.44 \pm 0.07$ & $0.93 \pm 0.04$ & $1.32 \pm 0.21$ \\
\hline Control (no P) & Mycorrhizal & $0.49 \pm 0.07$ & $1.09 \pm 0.07$ & $1.80 \pm 0.19$ & $0.11 \pm 0.01$ & $0.34 \pm 0.05$ & $0.42 \pm 0.03$ & $0.60 \pm 0.07$ & $1.43 \pm 0.11$ & $2.22 \pm 0.18$ \\
\hline $\mathrm{KH}_{2} \mathrm{PO}_{4}$ & Non-mycorrhizal & $0.45 \pm 0.08$ & $0.74 \pm 0.01$ & $1.02 \pm 0.06$ & $0.15 \pm 0.05$ & $0.24 \pm 0.01$ & $0.30 \pm 0.04$ & $0.60 \pm 0.11$ & $0.98 \pm 0.02$ & $1.32 \pm 0.03$ \\
\hline Lecithin & Non-mycorrhizal & $0.39 \pm 0.10$ & $0.72 \pm 0.04$ & $1.09 \pm 0.11$ & $0.11 \pm 0.02$ & $0.28 \pm 0.02$ & $0.29 \pm 0.03$ & $0.49 \pm 0.12$ & $1.00 \pm 0.06$ & $1.38 \pm 0.12$ \\
\hline Lecithin & Mycorrhizal & $0.49 \pm 0.07$ & $1.18 \pm 0.12$ & $2.07 \pm 0.22$ & $0.14 \pm 0.02$ & $0.45 \pm 0.03$ & $0.44 \pm 0.04$ & $0.63 \pm 0.09$ & $1.63 \pm 0.15$ & $2.51 \pm 0.25$ \\
\hline RNA & Non-mycorrhizal & $0.42 \pm 0.04$ & $0.77 \pm 0.08$ & $1.05 \pm 0.01$ & $0.12 \pm 0.03$ & $0.22 \pm 0.03$ & $0.25 \pm 0.03$ & $0.54 \pm 0.04$ & $0.99 \pm 0.11$ & $1.30 \pm 0.03$ \\
\hline RNA & Mycorrhizal & $0.49 \pm 0.09$ & $1.21 \pm 0.11$ & $1.92 \pm 0.25$ & $0.12 \pm 0.02$ & $0.33 \pm 0.06$ & $0.43 \pm 0.09$ & $0.61 \pm 0.08$ & $1.54 \pm 0.12$ & $2.35 \pm 0.33$ \\
\hline Na-phytate & Non-mycorrhizal & $0.40 \pm 0.09$ & $0.74 \pm 0.03$ & $1.19 \pm 0.19$ & $0.10 \pm 0.02$ & $0.24 \pm 0.03$ & $0.28 \pm 0.05$ & $0.50 \pm 0.10$ & $0.98 \pm 0.05$ & $1.47 \pm 0.23$ \\
\hline 'AM control' & Mycorrhizal & $0.40 \pm 0.04$ & $0.93 \pm 0.04$ & $1.64 \pm 0.12$ & $0.10 \pm 0.01$ & $0.39 \pm 0.06$ & $0.43 \pm 0.04$ & $0.50 \pm 0.04$ & $1.31 \pm 0.10$ & $2.07 \pm 0.15$ \\
\hline
\end{tabular}

Significance due to:

Applied P source

Mycorrhizal stat
Harvest time

P source $\times$ mycorrhizal stat

P source $\times$ harvest time

Mycorrhizal status $\times$ harvest time

P source $\times$ mycorrhiza $\times$ harvest time

NS
$* * *$
$* * *$
NS
NS
$* * *$
NS

$* * *$
$* * *$
$* * *$
NS
$*$
$* * *$

NS

Values are means $(n=4) \pm$ S.D. 
Table 3

Shoot and root $\mathrm{P}$ concentration in mycorrhizal or non-mycorrhizal red clover plants $\left(\mathrm{mg} \mathrm{P} \mathrm{g}^{-1}\right)$ at different stages of plant growth with applied inorganic-P or organic-P

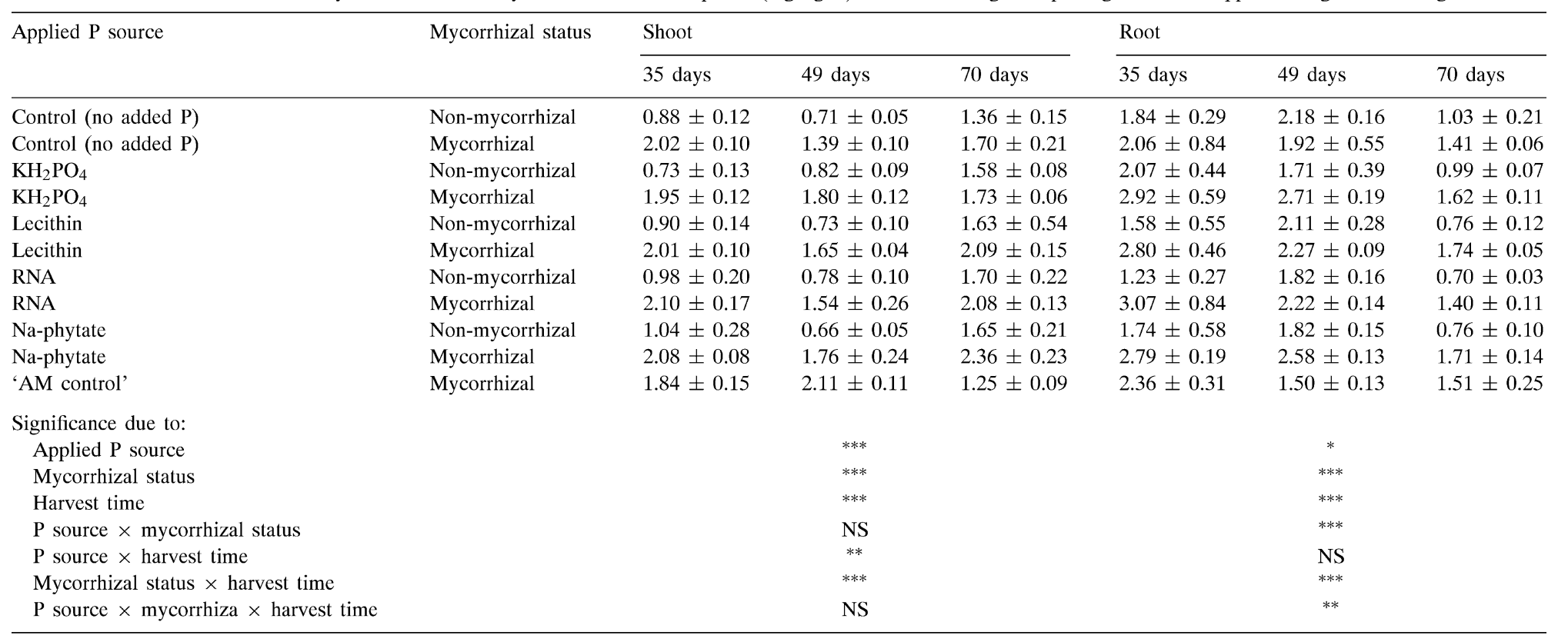

Values are means $(n=4) \pm$ S.D. 
Table 4

Shoot, root and total (root + shoot) P uptake by mycorrhizal and non-mycorrhizal red clover plants (mg per pot) at different stages of plant growth with applied inorganic-P or organic-P

\begin{tabular}{|c|c|c|c|c|c|c|c|c|c|c|}
\hline \multirow[t]{2}{*}{ Applied P source } & \multirow[t]{2}{*}{ Mycorrhizal status } & \multicolumn{3}{|l|}{ Shoot } & \multicolumn{3}{|l|}{ Root } & \multicolumn{3}{|l|}{ Total } \\
\hline & & 35 days & 49 days & 70 days & 35 days & 49 days & 70 days & 35 days & 49 days & 70 days \\
\hline Control (no P) & Non-mycorrhizal & $0.31 \pm 0.08$ & $0.48 \pm 0.06$ & $1.45 \pm 0.39$ & $0.16 \pm 0.03$ & $0.55 \pm 0.06$ & $0.26 \pm 0.06$ & $0.47 \pm 0.06$ & $1.03 \pm 0.10$ & $1.73 \pm 0.45$ \\
\hline Control (no P) & Mycorrhizal & $1.00 \pm 0.13$ & $1.53 \pm 0.19$ & $3.05 \pm 0.34$ & $0.23 \pm 0.07$ & $0.66 \pm 0.27$ & $0.59 \pm 0.03$ & $1.23 \pm 0.11$ & $2.19 \pm 0.44$ & $3.64 \pm 0.32$ \\
\hline $\mathrm{KH}_{2} \mathrm{PO}_{4}$ & Non-mycorrhizal & $0.33 \pm 0.09$ & $0.60 \pm 0.07$ & $1.61 \pm 0.07$ & $0.32 \pm 0.17$ & $0.42 \pm 0.12$ & $0.30 \pm 0.04$ & $0.65 \pm 0.20$ & $1.03 \pm 0.18$ & $1.91 \pm 0.07$ \\
\hline $\mathrm{KH}_{2} \mathrm{PO}_{4}$ & Mycorrhizal & $1.00 \pm 0.22$ & $2.10 \pm 0.13$ & $3.43 \pm 0.31$ & $0.49 \pm 0.18$ & $0.96 \pm 0.08$ & $0.68 \pm 0.07$ & $1.49 \pm 0.37$ & $3.06 \pm 0.15$ & $4.11 \pm 0.35$ \\
\hline Lecithin & Non-mycorrhizal & $0.34 \pm 0.07$ & $0.52 \pm 0.08$ & $1.77 \pm 0.55$ & $0.16 \pm 0.02$ & $0.59 \pm 0.11$ & $0.23 \pm 0.06$ & $0.50 \pm 0.06$ & $1.11 \pm 0.16$ & $1.99 \pm 0.53$ \\
\hline Lecithin & Mycorrhizal & $0.99 \pm 0.17$ & $1.94 \pm 0.18$ & $4.29 \pm 0.18$ & $0.39 \pm 0.09$ & $1.02 \pm 0.06$ & $0.77 \pm 0.07$ & $1.38 \pm 0.26$ & $2.95 \pm 0.21$ & $5.06 \pm 0.24$ \\
\hline RNA & Non-mycorrhizal & $0.42 \pm 0.12$ & $0.61 \pm 0.13$ & $1.79 \pm 0.24$ & $0.14 \pm 0.05$ & $0.40 \pm 0.04$ & $0.17 \pm 0.01$ & $0.56 \pm 0.14$ & $1.01 \pm 0.16$ & $1.95 \pm 0.25$ \\
\hline RNA & Mycorrhizal & $1.02 \pm 0.15$ & $1.86 \pm 0.33$ & $4.01 \pm 0.75$ & $0.35 \pm 0.08$ & $0.73 \pm 0.17$ & $0.59 \pm 0.08$ & $1.37 \pm 0.14$ & $2.59 \pm 0.49$ & $4.60 \pm 0.82$ \\
\hline Na-phytate & Non-mycorrhizal & $0.40 \pm 0.09$ & $0.49 \pm 0.06$ & $1.93 \pm 0.17$ & $0.17 \pm 0.06$ & $0.44 \pm 0.05$ & $0.22 \pm 0.06$ & $0.57 \pm 0.10$ & $0.93 \pm 0.11$ & $2.14 \pm 0.19$ \\
\hline 'AM control' & Mycorrhizal & $0.74 \pm 0.10$ & $1.96 \pm 0.13$ & $2.06 \pm 0.17$ & $0.23 \pm 0.03$ & $0.58 \pm 0.12$ & $0.65 \pm 0.15$ & $0.97 \pm 0.10$ & $2.54 \pm 0.23$ & $2.71 \pm 0.28$ \\
\hline \multicolumn{11}{|l|}{ Significance due to: } \\
\hline Applied P source & & & $* * *$ & & & $* * *$ & & & $* * *$ & \\
\hline Mycorrhizal status & & & $* * *$ & & & **** & & & $* * *$ & \\
\hline Harvest time & & & $* * *$ & & & *** & & & $* * *$ & \\
\hline P source $\times$ mycorrhizal status & & & ** & & & **** & & & *** & \\
\hline$P$ source $\times$ harvest time & & & **** & & & * & & & $* * *$ & \\
\hline Mycorrhizal status $x$ harvest time & & & **** & & & **** & & & $* * *$ & \\
\hline P source $\times$ mycorrhiza $\times$ harvest time & & & *** & & & NS & & & $* *$ & \\
\hline
\end{tabular}

Values are means $(n=4) \pm$ S.D. 
Table 5

Calculated P derived from four applied $\mathrm{P}$ sources before sowing by mycorrhizal and non-mycorrhizal red clover at different stages of plant growth (mg per pot) and the contribution to plant $\mathrm{P}$ uptake by the external mycelium from the $\mathrm{P}$ sources applied to the outer compartments (mg per pot)

\begin{tabular}{|c|c|c|c|c|c|c|c|}
\hline \multirow[t]{2}{*}{ Applied P source } & \multirow[t]{2}{*}{ Mycorrhizal status } & \multicolumn{3}{|c|}{$\mathrm{P}$ derived from applied $\mathrm{P}$} & \multicolumn{3}{|c|}{ P uptake by mycelium } \\
\hline & & 35 days & 49 days & 70 days & 35 days & 49 days & 70 days \\
\hline $\mathrm{KH}_{2} \mathrm{PO}_{4}$ & Non-mycorrhizal & 0.10 & 0.00 & 0.43 & $\mathrm{NA}^{\mathrm{a}}$ & NA & NA \\
\hline $\mathrm{KH}_{2} \mathrm{PO}_{4}$ & Mycorrhizal & 0.26 & 0.87 & 1.66 & 0.16 & 0.87 & 1.23 \\
\hline Lecithin & Non-mycorrhizal & 0.03 & 0.08 & 0.24 & NA & NA & NA \\
\hline Lecithin & Mycorrhizal & 0.15 & 0.76 & 1.41 & 0.08 & 0.66 & 1.17 \\
\hline RNA & Non-mycorrhizal & 0.09 & -0.02 & 0.28 & NA & NA & NA \\
\hline RNA & Mycorrhizal & 0.14 & 0.40 & 1.11 & 0.05 & 0.4 & 0.83 \\
\hline Na-phytate & Non-mycorrhizal & 0.10 & -0.10 & 0.22 & NA & NA & NA \\
\hline Na-phytate & Mycorrhizal & 0.14 & 0.52 & 2.02 & 0.04 & 0.52 & 1.80 \\
\hline
\end{tabular}

Values calculated from mean of four replicates (see text for details).

${ }^{\text {a }} \mathrm{NA}$, not applicable to non-mycorrhizal treatments.

Table 6

Calculated AM mycorrhizal hyphal contribution to (a) plant total P uptake, (b) plant uptake of applied P and (c) plant uptake of native soil P (all expressed as \% of plant uptake) at different stages of growth of mycorrhizal red clover plants

\begin{tabular}{|c|c|c|c|c|c|c|c|c|c|}
\hline \multirow[t]{2}{*}{ Applied P source } & \multicolumn{3}{|c|}{ (a) Total P } & \multicolumn{3}{|c|}{ (b) Applied P } & \multicolumn{3}{|c|}{ (c) Native soil P } \\
\hline & 35 days & 49 days & 70 days & 35 days & 49 days & 70 days & 35 days & 49 days & 70 days \\
\hline Control (no added P) & 62 & 53 & 53 & 0 & 0 & 0 & 100 & 100 & 100 \\
\hline $\mathrm{KH}_{2} \mathrm{PO}_{4}$ & 62 & 66 & 60 & 11 & 28 & 23 & 89 & 72 & 77 \\
\hline Lecithin & 64 & 62 & 61 & 6 & 22 & 23 & 94 & 78 & 77 \\
\hline RNA & 59 & 61 & 58 & 4 & 15 & 17 & 96 & 85 & 83 \\
\hline Na-phytate & 58 & 66 & 66 & 3 & 19 & 31 & 97 & 81 & 69 \\
\hline
\end{tabular}

Values calculated from means of four replicates (see text for details).

corrhizal plants receiving organic sources of $\mathrm{P}$ (with the possible exception of RNA) had taken up more total $\mathrm{P}$ than plants growing with added $\mathrm{KH}_{2} \mathrm{PO}_{4}$.

\subsection{Contribution of hyphal $P$ uptake from the $P$ sources applied to the outer compartments}

In our experimental design, there were two main sources of P: native soil P and applied P, with only native soil $\mathrm{P}$ available to the controls. The calculated plant $\mathrm{P}$ uptake derived from applied $\mathrm{P}$ sources and the $\mathrm{P}$ taken up by mycelium from the hyphal compartments are shown in Table 5. In turn, these estimates were used to calculate the hyphal contribution to $\mathrm{P}$ absorption from different sources and the results are presented in Table 6.

The hyphal contribution to uptake of different organic $\mathrm{P}$ sources by red clover increased with time. In the fifth and the seventh weeks, the hyphal contribution to uptake of the three organic $\mathrm{P}$ sources was lower than that of $\mathrm{KH}_{2} \mathrm{PO}_{4}$, with sodium phytate showing the smallest contribution. At the final harvest, the highest hyphal contribution to $\mathrm{P}$ uptake was $31 \%$ from sodium phytate. The value for both $\mathrm{KH}_{2} \mathrm{PO}_{4}$ and lecithin was $23 \%$ and for RNA was $17 \%$ (Table 6).

\section{Discussion}

Although organic $\mathrm{P}$ typically represents a major fraction of soil $\mathrm{P}$ and some organic $\mathrm{P}$ compounds (e.g. phytin, lecithin and glycerophosphate) are very important in the P nutrition of plants (Tarafdar and Claassen, 1988), the contribution of soil organic compounds to plant $\mathrm{P}$ nutrition is still poorly understood. Moreover, we are not aware of any published investigations on the contribution of AM external mycelium to host plant $\mathrm{P}$ uptake from organic sources. The present study has 
allowed some quantitative evaluation of the contribution of some principal forms of organic $\mathrm{P}$ to plants with or without AM fungal colonization. The results show that when the roots of red clover were confined to the central compartment of the rhizoboxes the extraradical mycelium made a contribution of 53-65\% of plant P uptake from the soil, 17-31\% of which was derived from organic P. This implies that the contribution of AM hyphae to plant $\mathrm{P}$ nutrition by absorbing from the organic $\mathrm{P}$ pool in soil can be considerable (Table 6) and indicates that AM fungi may play an important role in cycling of organic $\mathrm{P}$ in the soil. The fully randomized experimental design used was not optimal for this work because it did not permit the calculation of independent replicate estimates of the hyphal contribution to plant $\mathrm{P}$ uptake that would have been possible using a randomized block design. Nevertheless, it did permit the calculation of mean values for the hyphal contribution to $\mathrm{P}$ uptake from different organic $\mathrm{P}$ compounds.

To evaluate the uptake of $\mathrm{P}$ from phosphates applied in hyphal compartments by AM hyphae the rhizosphere effect of roots and native soil $\mathrm{P}$ should be taken into account and subtracted from the total $\mathrm{P}$ uptake of mycorrhizal plants. According to the experimental design, significantly higher yields and $\mathrm{P}$ uptake in mycorrhizal plants compared with non-mycorrhizal plants at a given $P$ status implies that the extraradical mycelium made a substantial contribution by absorbing $\mathrm{P}$, including native soil $\mathrm{P}$ and applied $\mathrm{P}$, from the hyphal compartments. The observed higher yields, shoot and root $\mathrm{P}$ concentrations and higher $\mathrm{P}$ uptake values in mycorrhizal plants with applied phytate, lecithin and RNA compared with mycorrhizal zero-P controls indicate that AM extraradical mycelium can increase the bioavailibility of these three principal forms of soil organic $\mathrm{P}$. The higher yields, plant $\mathrm{P}$ concentrations and $\mathrm{P}$ uptake sometimes observed in non-mycorrhizal plants that received applied phytate, lecithin and RNA compared with mycorrhizal controls demonstrates a marked rhizosphere effect of plant roots on uptake of organic and inorganic P. The rhizosphere effect not only increased $\mathrm{P}$ uptake from both inorganic and organic P sources, but also promoted plant growth and this indicates that plant roots may be able to utilize phytate, lecithin and RNA directly. These effects may have been due to the release of acid phosphatase and phytase from the plant roots (Li et al., 1997a,b; Shand and Smith, 1997; Hayes et al., 1999).
The abundance of the three principal forms of soil organic $\mathrm{P}$ follows the order inositol phosphate $\gg$ phospholipds $>$ nucleic acid. However, the same types of organic $\mathrm{P}$ compounds are found in plants in the reverse order of abundance (Stevenson and Cole, 1999). The accumulation of phytate in soils indicates that it is resistant to rapid mineralization (Anderson, 1980). In contrast, organic P compounds such as glucose 1-phosphate, nucleic acid and phospholipids may be mineralized more readily (Dalal, 1977). The results of the present study indicate that when organic P sources such as phytate and lecithin are present at the same concentration as $\mathrm{KH}_{2} \mathrm{PO}_{4}$ in soil, they may make a similar contribution to plant growth and $\mathrm{P}$ nutrition compared with soluble inorganic phosphorus.

The $\mathrm{P}$ in organic compounds can become available to plants after hydrolysis by phosphatase enzymes. It has been suggested that AM fungi are able to produce acid phosphatase that is released into the soil (Joner and Johansen, 2000; Saito, 1995) and enhance the soil acid phosphatase activity (Tarafdar and Marschner, 1995; Feng et al., 2002; Song et al., 2000). A recent report showed that the extraradical hyphae of Glomus intraradices can hydrolyze 5-bromo-4-chloro-3-indolyl phosphate, phenolphthalein diphosphate and phytate under axenic culture conditions (Koide and Kabir, 2000). In this study, unlike the inorganic phosphate $\left(\mathrm{KH}_{2} \mathrm{PO}_{4}\right)$, the bioavailability of the organic $\mathrm{P}$ sources (phytate, lecithin and RNA) increased with the increasing growth stage of plant and AM fungus (Tables 2 and 4). This may be attributed to an increase in the activity of acid and alkaline phosphatases in soil by the extraradical hyphae of AM fungi (unpublished data). Numerous studies have demonstrated that extraradical hyphae can increase the acid or alkaline phosphatase activities of soil (Feng et al., 2002; Song et al., 2000; Tarafdar and Marschner, 1994, 1995).

The role of phytase released by plant roots in decomposition of phytate in soil has received much interest in recent years (Hayes et al., 1999, 2000a; Richardson et al., 2000; Li et al., 1997a,b; Shand and Smith, 1997). Phytase is believed to lack specificity and can hydrolyze bonds in a range of substrates including monoesters, a complex diester (RNA), pyrophosphate, a linear polyphosphate and a cyclic polyphosphate (Shand and Smith, 1997). However, whether or not AM hyphae can produce and release 
phytase is still unknown and further studies are required to elucidate this.

\section{Acknowledgements}

This study was supported financially by the Major State Basic Research Development Program of China (Project G1999011807), the National Natural Science Foundation of China (Project 40071050) and the British Council (Link Project PEK/992/314). We also thank two anonymous referees for their valuable comments on the manuscript.

\section{References}

Anderson, G., 1980. Assessing organic phosphorus in soil. In: Khasawneh, F.E., Sample, E.C., Kamprath, E.J. (Eds.), The Role of Phosphorus in Agriculture. American Society of Agronomy, Madison, WI, pp. 411-431.

Bowman, R.A., Cole, C.V., 1978. Transformation of organic phosphorus substrates in soils as evaluated by $\mathrm{NaHCO}_{3}$ extraction. Soil Sci. 125, 49-54.

Cade-Menun, B.J., Berch, S.M., 1997. Response of mycorrhizal western red cedar to organic phosphorus sources and benomyl. Can. J. Bot. 75, 1226-1235.

Dalal, R.C., 1977. Soil organic phosphorus. Adv. Agron. 29, 83117.

Feng, G., Su, Y.B., Li, X.L., Wang, H., Zhang, F.S., Tang, C., Rengel, Z., 2002. Histochemical visualization of phosphatase released by arbuscular mycorrhizal fungi in soil. J. Plant Nutr. 25, 969-980.

GENSTAT Committee, 1994. GENSTAT 5 Reference Manual. Clarendon Press, Oxford.

Giovannetti, M., Mosse, B., 1980. An evaluation of techniques for measuring vesicular-arbuscular mycorrhizal infection in roots. New Phytol. 84, 489-500.

Hayes, J.E., Richardson, A.E., Simpson, R.J., 1999. Phytase and acid phosphatase activities in extracts from roots of temperate pasture grass and legume seedling. Aust. J. Plant Physiol. 26, 801-809.

Hayes, J.E., Richardson, A.E., Simpson, R.J., 2000a. Components of organic phosphorus in soil extracts that are hydrolysed by phytase and acid phosphatase. Biol. Fertil. Soils 32, 279-286.

Hayes, J.E., Simpson, R.J., Richardson, A.E., 2000b. The growth and phosphorus utilisation of plants in sterile media when supplied with inositol hexaphosphate, glucose 1-phosphate or inorganic phosphate. Plant Soil 220, 165-174.

Jayachandran, K., Schwab, A.P., Hetrick, B.A.D., 1992. Mineralization of organic phosphorus by vesicular-arbuscular mycorrhizal fungi. Soil Biol. Biochem. 24, 897-903.

Joner, E.J., Jakobsen, I., 1994. Contribution by two arbuscular mycorrhizal fungi to $\mathrm{P}$ uptake by cucumber (Cucumis sativus L.) from ${ }^{32} \mathrm{P}$-labelled organic matter during mineralization in soil. Plant Soil 163, 203-209.
Joner, E.J., Johansen, A., 2000. Phosphatase activity of external hyphae of two arbuscular mycorrhizal fungi. Mycol. Res. 104, $81-86$.

Joner, E.J., van Aarle, I.M., Vosatka, M., 2000. Phosphatase activity of extra-radical arbuscular mycorrhizal hyphae: a review. Plant Soil 226, 199-210.

Kitson, R.E., Mellon, M.G., 1944. Colorimetric determination of phosphorus as molybdovanado phosphoric acid. Ind. Eng. Chem. Anal. Ed. 16, 554-557.

Koide, R.T., Kabir, Z., 2000. Extraradical hyphae of the mycorrhizal fungus Glomus intraradices can hydrolyse organic phosphate. New Phytol. 148, 511-517.

Li, M.G., Osaki, M., Rao, I.M., Tadano, T., 1997a. Secretion of phytase from the roots of several plant species under phosphorus deficient conditions. Plant Soil 195, 161-169.

Li, M.G., Osaki, M., Rao, I.M., Tadano, T., 1997b. Purification and characterization of phytase induced in tomato roots under phosphorus-deficient conditions. Soil Sci. Plant Nutr. 43, 179190.

Li, X.L., George, E., Marschner, H., 1991. Extension of the phosphorus depletion zone in VA-mycorrhizal white clover in a calcareous soil. Plant Soil 36, 41-48.

Richardson, A.E., Hadobas, P.A., 1997. Soil isolates of Pseudomonas spp. that utilize inositol phosphates. Can. J. Microbiol. 43, 509-516.

Richardson, A.E., Hadobas, P.A., Hayes, J.E., 2000. Acid phosphomonoesterase and phytase activities of wheat (Triticum aestivum L.) roots and utilization of organic phosphorus substrates by seedlings grown in sterile culture. Plant Cell Environ. 23, 397-405.

Saito, M., 1995. Enzyme activities of the internal hyphae and germinated spores of an arbuscular mycorrhizal fungus, Gigaspora margarita Becker \& Hall. New Phytol. 129, 3.

Shand, C.A., Smith, S., 1997. Enzymatic release of phosphate from model substrates and $\mathrm{P}$ compounds in soil solution from a peaty podzol. Biol. Fertil. Soils 24, 183-187.

Song, Y.C., Li, X.L., Feng, G., Zhang, F.S., Christie, P., 2000. Rapid assessment of acid phosphatase activity in the mycorrhizosphere and in arbuscular mycorrhizal fungal hyphae. Chin. Sci. Bull. 45, 1187-1190.

Stevenson, F.J., Cole, M.A., 1999. Cycles of Soil: Carbon, Nitrogen, Phosphorus, Sulfur, Micronutrients, 2nd ed. Wiley, New York, pp. 279-329.

Tarafdar, J.C., Claassen, N., 1988. Organic phosphorus compounds as a phosphorus source for higher plants through the activity of phosphatases produced by plant roots and microorganisms. Biol. Fertil. Soils 5, 308-312.

Tarafdar, J.C., Marschner, H., 1994. Phosphatase activity in the rhizosphere and hyphosphere of VA-mycorrhizal wheat supplied with inorganic and organic phosphorus. Soil Biol. Biochem. 26, 387-395.

Tarafdar, J.C., Marschner, H., 1995. Dual inoculation with Aspergillus fumigatus and Glomus mosseae enhances biomass production and nutrient uptake in wheat (Triticum aestivum L.) supplied with organic phosphorus as Na-phytate. Plant Soil 173, 97-102.

Theodorou, C., 1971. The phytase activity of the mycorrhizal fungus Rhizopogon luteolus. Soil Biol. Biochem. 3, 89-90. 